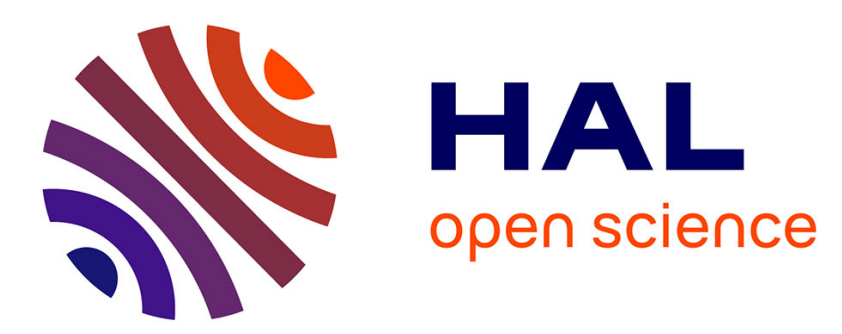

\title{
Reactions of diethylamine and ethylene catalyzed by Pt II or Pt 0 : transalkylation vs. hydroamination
}

\author{
Pavel Dub, Aurélien Béthegnies, Rinaldo Poli
}

\section{To cite this version:}

Pavel Dub, Aurélien Béthegnies, Rinaldo Poli. Reactions of diethylamine and ethylene catalyzed by Pt II or Pt 0: transalkylation vs. hydroamination. European Journal of Inorganic Chemistry, 2011, 2011 (33), pp.5167-5172. 10.1002/ejic.201100624 . hal-03157864

\section{HAL Id: hal-03157864 https://hal.science/hal-03157864}

Submitted on 3 Mar 2021

HAL is a multi-disciplinary open access archive for the deposit and dissemination of scientific research documents, whether they are published or not. The documents may come from teaching and research institutions in France or abroad, or from public or private research centers.
L'archive ouverte pluridisciplinaire $\mathbf{H A L}$, est destinée au dépôt et à la diffusion de documents scientifiques de niveau recherche, publiés ou non, émanant des établissements d'enseignement et de recherche français ou étrangers, des laboratoires publics ou privés. 


\title{
Reactions of diethylamine and ethylene catalyzed by $\mathbf{P t}^{\mathrm{II}}$ or $\mathbf{P t}^{0}$ : transalkylation $v s$. hydroamination
}

\author{
Pavel A. Dub, ${ }^{[a]}$ Aurélien Béthegnies ${ }^{[a]}$ and Rinaldo Poli*[a],[b]
}

Keywords: Platinum / Ethylene hydroamination / Amine transalkylation / DFT calculations / Aqueous catalysis

$\mathrm{PtBr}_{2} / n \mathrm{Bu}_{4} \mathrm{PBr}$ (without solvent) or $\mathrm{K}_{2} \mathrm{PtCl}_{4} / \mathrm{NaBr}$ (in water), previously shown to efficiently catalyze the hydroamination of ethylene by aniline, are poor catalysts for the hydroamination of ethylene by diethylamine. A DFT study on the hydroamination mechanism indicates that the energetic span of the $\mathrm{C}_{2} \mathrm{H}_{4} / \mathrm{Et}_{2} \mathrm{NH}$ catalytic cycle is close to that of the $\mathrm{C}_{2} \mathrm{H}_{4} / \mathrm{PhNH}_{2}$ cycle. The poor

[a] CNRS; LCC (Laboratoire de Chimie de Coordination); Université de Toulouse; UPS, INP ; 205, route de Narbonne, F-31077 Toulouse, France

Fax: (+33) 561553003

E-mail: rinaldo.poli@1cc-toulouse.fr

[b] Institut Universitaire de France; 103, bd Saint-Michel, 75005 Paris, France

Supporting information for this article is available on the WWW under http://www.eurjic.org/ or from the author.

\section{Introduction}

Amines are important compounds for the bulk and fine chemical industries. There is great current interest in optimizing the hydroamination reaction, an atom economical process that results in the $\mathrm{N}-\mathrm{H}$ addition of ammonia or an amine to an unsaturated substrate to produce a higher amine. ${ }^{[1]}$ Amongst all the hydroamination reactions, the most difficult one is the intermolecular version with non-activated olefins and solutions based on transition metal catalysis are actively pursued. ${ }^{[1-3]}$ With regard to industrial applications, short chain aliphatic olefins and especially ethylene constitute the most attractive starting materials. In the last 6 years a number of papers have appeared on the hydroamination of ethylene and other $\alpha$-olefins catalysed in particular by Pt-based systems. These include the addition of substituted anilines to ethylene ${ }^{[4]}$ and 1 -hexene ${ }^{[5]}$ catalyzed by $\mathrm{PtBr}_{2} / n-\mathrm{Bu}_{4} \mathrm{PBr}(\mathbf{I})$, including our recent extension to aqueous media $\left(\mathrm{PtBr}_{2} / \mathrm{NaBr}_{(\mathrm{aq})}, \mathbf{I}^{\prime}\right),{ }^{[6]}$ the addition of carboxamides to $\mathrm{RHC}=\mathrm{CH}_{2}(\mathrm{R}$ $=\mathrm{H}, \mathrm{Me}$ ) catalyzed by $\left[\mathrm{PtCl}_{2}\left(\mathrm{H}_{2} \mathrm{C}=\mathrm{CH}_{2}\right)\right]_{2} / \mathrm{PPh}_{3}(\mathbf{I I})^{[7]}$ and that of sulfonamides or anilines to more strained olefins catalyzed by (COD)Pt(OTf $)_{2}$ (III). ${ }^{[8]}$ For each type of catalyst the turnover number (TON) or product yield was shown to increase as the amine basicity decreases and no activity was found when the conjugate acid of the amine has a $\mathrm{pK}_{\mathrm{a}}$ value above a certain cut-off value. Although comparisons are complicated by the different conditions used for each of these three catalytic systems, I appears the most active one, allowing ethylene hydroamination with 4- $\mathrm{MeOC}_{6} \mathrm{H}_{4} \mathrm{NH}_{2}$ - the most basic amine for which an activity has been reported for a Pt-based catalyst. ${ }^{[4]}$ Attempts to probe more basic amines for system I were not performed, probably because of expectations on the basis of the observed $\mathrm{pK}_{\mathrm{a}}$ trend. Attempts to use more basic secondary amines were described only for system II, with negative results performance is attributed to rapid catalyst degradation with reduction to metallic platinum. The produced $\mathrm{Pt}^{0}$, on the other hand, catalyzes a transalkylation process, partially transforming $\mathrm{Et}_{2} \mathrm{NH}$ into $\mathrm{Et}_{3} \mathrm{~N}, \mathrm{EtNH}_{2}$, and $\mathrm{NH}_{3}$. The latter process is inhibited by $\mathrm{C}_{2} \mathrm{H}_{4}$. Mechanistic considerations on the $\mathrm{Pt}^{0}-$ catalyzed transalkylation process are presented.

when using secondary amines. ${ }^{[7]}$ The catalytic system III was shown to be inactive already when using aniline $\left(\mathrm{pK}_{\mathrm{a}}=4.63\right) .{ }^{\left[{ }^{[}\right]}$

In recent work, we have explored the details of the $\mathrm{PtBr}_{2} / \mathrm{Br}$ catalyzed addition of aniline to ethylene at the experimental and computational levels, by isolating a number of low-energy intermediates and off-loop species and studying their solution equilibria, ${ }^{[9]}$ and by carrying out a computational investigation of the catalytic cycle, ${ }^{[10-11]}$ the main features of which are summarized in Scheme 1. The nucleophilic addition to the coordinated and activated ethylene substrate is more facile for the neutral compound trans-[ $\left.\mathrm{PtBr}_{2}\left(\mathrm{NHEt}_{2}\right)\left(\mathrm{C}_{2} \mathrm{H}_{4}\right)\right]$ (2), and also for the bis(ethylene) complex trans- $\left[\mathrm{PtBr}_{2}\left(\mathrm{C}_{2} \mathrm{H}_{4}\right)_{2}\right]$ (not shown in Scheme 1), than for the anionic resting state $\left[\mathrm{PtBr}_{3}\left(\mathrm{C}_{2} \mathrm{H}_{4}\right)\right]^{-}(\mathbf{1})$, but the only zwitterionic intermediate capable to complete the catalytic cycle is $\left[\mathrm{Br}_{3} \mathrm{Pt}^{(2-)}\left(\mathrm{CH}_{2} \mathrm{CH}_{2} \mathrm{~N}^{(+)} \mathrm{H}_{2} \mathrm{Ph}\right)\right](4)$, obtainable directly from $\mathbf{1}$

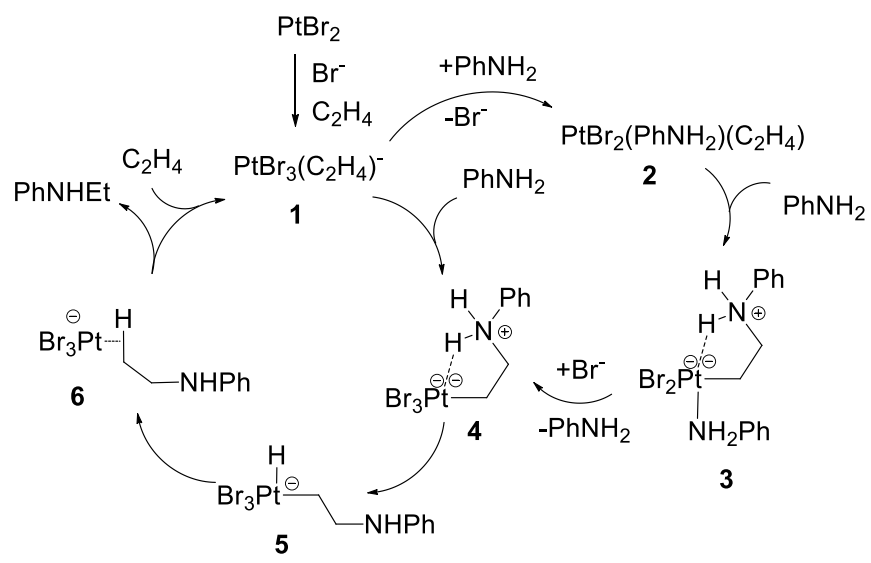

Scheme 1. Mechanism of the $\mathrm{PtBr}_{2} / \mathrm{Br}^{-}$catalyzed hydroamination of ethylene by aniline.

Since the zwitterionic intermediates invoked for this system, such as $\mathbf{3}$ and $\mathbf{4}$, are too high in energy to be experimentally observed, we have carried out model investigations using the more basic and nucleophilic $\mathrm{Et}_{2} \mathrm{NH}$, obtaining direct evidence for the generation of the zwitterionic adduct $\left[\left(\mathrm{Et}_{2} \mathrm{HN}\right) \mathrm{Br}_{2} \mathrm{Pt}^{(-)} \mathrm{CH}_{2} \mathrm{CH}_{2} \mathrm{~N}^{(+)} \mathrm{HEt}_{2}\right]{ }^{[12]} \mathrm{An}$ excess amount of $\mathrm{NHEt}_{2}$ was shown to promote an equilibrium 
deprotonation of this species, yielding the aminoalkyl derivative $\left[\left(\mathrm{Et}_{2} \mathrm{~N}\right) \mathrm{Br}_{2} \mathrm{PtCH}_{2} \mathrm{CH}_{2} \mathrm{NEt}_{2}\right]^{-}$, which then decomposes by giving rise to the deposition of $\mathrm{Pt}^{0}$ and to the generation of other uncharacterized species. This behaviour is similar to that of other complexes obtained by addition of basic amines to Pt-coordinated olefins. ${ }^{[13-15]}$ This observation suggests that the catalyst deactivation process is triggered by the deprotonation of the intermediate zwitterionic species and this hypothesis has been confirmed by new catalytic tests: the addition of strong bases $\left(\mathrm{KOH}, \mathrm{NHEt}_{2}, \mathrm{NEt}_{3}\right.$, or $\mathrm{DBU})$ to the catalytic medium completely suppresses the production of the PhNHEt product, while the $\mathrm{Pt}^{\mathrm{II}}$ catalyst is completely converted into metallic platinum. ${ }^{[16]}$

In this report, we present two new principles. The first one, derived from a computational investigation on the catalytic cycle with NHEt 2 , is that more basic amines are indeed kinetically competent to complete the hydroamination catalytic cycle. Hence, the lack of catalysis is not due to an intrinsic lower catalytic efficiency but must be attributed to the above mentioned catalyst decomposition triggered by deprotonation, which is more favourable for stronger bases. The second one, derived from further catalytic experiments, deals with the discovery of a competitive amine transalkylation process, which is catalyzed by $\mathrm{Pt}^{0}$ under the hydroamination conditions.

\section{Results and Discussion}

\section{(a) Initial catalytic tests.}

We first attempted the ethylene hydroamination by HNEt 2 under the same conditions previously used for the hydroamination of ethylene by aniline $\left(\mathrm{PtBr}_{2} / n \mathrm{Bu}_{4} \mathrm{PBr} \text { catalyst, } \mathbf{I}\right)^{[4]}$ and also under our recent extension of this system to aqueous media $\left(\mathrm{K}_{2} \mathrm{PtCl}_{4} / \mathrm{NaBr}\left(\mathrm{H}_{2} \mathrm{O}\right)\right.$ catalyst, I'). ${ }^{[6]}$ These experiments yielded triethylamine in only close to stoichiometric amounts, see Table 1 (runs 1 and 2), while the starting compound conversion was negligible according to NMR. Extensive deposition of metallic Pt, as also reported for the aniline addition experiments, ${ }^{[4-6]}$ was observed at the end of the reaction. Surprisingly, ethylamine, the formal product of dehydroamination, was also observed as a coproduct in non negligible amounts.

Table 1. Pt-catalyzed hydroamination of $\mathrm{C}_{2} \mathrm{H}_{4}$ by $\mathrm{Et}_{2} \mathrm{NH}^{\text {[a] }}$

\begin{tabular}{cccc}
\hline run & cat. & Product (TON) & Other products (TON) \\
\hline 1 & $\mathbf{I}$ & $\mathrm{Et}_{3} \mathrm{~N}(\sim 1)$ & $\mathrm{EtNH}_{2}(3)$ \\
2 & $\mathbf{I}^{\text {‘ }}$ & $\mathrm{Et}_{3} \mathrm{~N}(\sim 2)$ & $\mathrm{EtNH}_{2}(5)$ \\
\hline
\end{tabular}

[a] Conditions: $[\mathrm{Pt}]=0.3 \%$ relative to amine; $[\mathrm{Br}] / \mathrm{Pt}=150 ; 15 \mathrm{ml}$ of $\mathrm{H}_{2} \mathrm{O}$ (only for system I'); 25 bar $\mathrm{C}_{2} \mathrm{H}_{4}$ at $298 \mathrm{~K}, 10 \mathrm{~h}, 150^{\circ} \mathrm{C}$.

We shall now first address the catalytic cycle of ethylene hydroamination by $\mathrm{NHEt}_{2}$ through a computational investigation, before analyzing the reason for the formation of the $\mathrm{EtNH}_{2}$ product.

(b) Computational investigation of the hydroamination mechanism with $\mathrm{Et}_{2} \mathrm{NH}$.

The energetics of the ethylene hydroamination by $\mathrm{Et}_{2} \mathrm{NH}$ were analyzed by DFT, according to the established mechanism for the addition of aniline (Scheme 1). ${ }^{[11]}$ In order to directly compare the results of the two system, the calculations were carried out at the same level of theory (see computational details). The addition of
$\mathrm{Et}_{2} \mathrm{NH}$ to $\mathrm{C}_{2} \mathrm{H}_{4}$ is exoergic by $\Delta \mathrm{G}^{\circ}{ }_{298}=-3.7 \mathrm{kcal} / \mathrm{mol}$ (cf. -6.0 for $\mathrm{PhNH}_{2}$ ) in the gas phase and $\Delta \mathrm{G}^{\circ}{ }_{298}{ }^{\mathrm{CPCM}}=-6.1 \mathrm{kcal} / \mathrm{mol}$ (cf. -8.0 for $\mathrm{PhNH}_{2}$ ) with inclusion of the solvent effect in aniline. The energetic details of the catalytic cycle are summarized in Figure 1. Beyond the generation of the zwitterion $\left[\left(\mathrm{Et}_{2} \mathrm{HN}\right) \mathrm{Br}_{2} \mathrm{Pt}^{(-)}\right.$$\mathrm{CH}_{2} \mathrm{CH}_{2} \mathrm{~N}^{(+)} \mathrm{HEt}_{2}$ ] (3'), which was also observed experimentally as already mentioned above, ${ }^{[12]}$ ligand exchange occurs to yield the tribromido derivative $\left[\mathrm{Pt}^{(2-)} \mathrm{Br}_{3}\left(\mathrm{CH}_{2} \mathrm{CH}_{2} \mathrm{~N}^{(+)} \mathrm{HEt}_{2}\right)\right]^{\prime}, 4^{\prime}$. Contrary to the $\mathrm{PhNH}_{2} / \mathrm{C}_{2} \mathrm{H}_{4}$ cycle, a local minimum could not be located for a 5-coordinate $\mathrm{Pt}^{\mathrm{IV}}$ hydride complex $\left[\mathrm{PtHBr}_{3}\left(\mathrm{CH}_{2} \mathrm{CH}_{2} \mathrm{NEt}_{2}\right)\right]^{-}\left(\mathbf{5}^{\prime}\right)$ derived from 4' by intramolecular proton transfer. Every attempt to optimize such a complex led back to $\mathbf{4}^{\prime}$, consistent with the greater basicity of the $\mathrm{N}$ atom relative to the aniline system. However, a transition state was located for transfer of the ammonium proton to the carbon atom, directly transforming 4' into the $\sigma$-complex $\left[\mathrm{PtBr}_{3}\left(\eta^{2}-\mathrm{H}-\mathrm{CH}_{2} \mathrm{CH}_{2} \mathrm{NEt}_{2}\right)\right]^{-}, \mathbf{6}^{\prime}$, from which the $\mathrm{Et}_{3} \mathrm{~N}$ product may be released by exchange with $\mathrm{C}_{2} \mathrm{H}_{4}$ to start a new cycle. This proton transfer is however assisted by the $\mathrm{Pt}$ atom, as shown by the relative short $\mathrm{Pt} \cdots \mathrm{H}$ contact in the transition state (Figure 1).

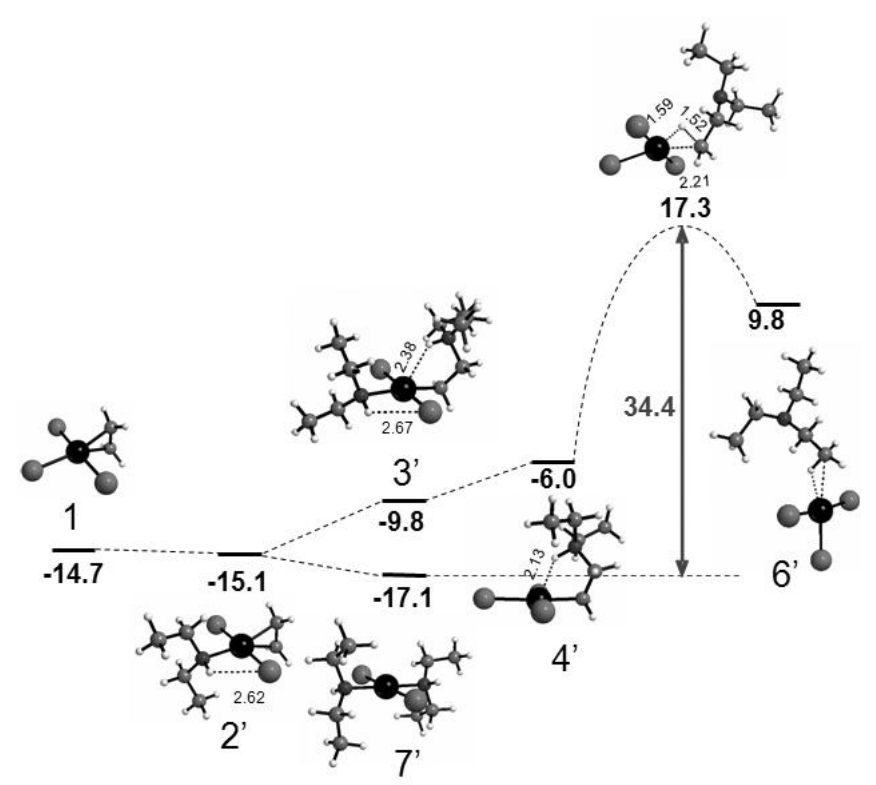

Figure 1. $\triangle \mathrm{G}^{\mathrm{CPCM}}$ (aniline) profile in $\mathrm{kcal} \mathrm{mol}^{-1}$ for the $\mathrm{C}_{2} \mathrm{H}_{4}$ hydroamination by $\mathrm{Et}_{2} \mathrm{NH}$ on the $\mathrm{PtBr}_{2} / \mathrm{Br}^{-}$catalytic system at $298.15 \mathrm{~K}$.

The overall barrier between the resting state and the ratedetermining transition state ${ }^{[17]}\left(34.4 \mathrm{kcal} \mathrm{mol}^{-1}\right)$, is not significantly higher than that calculated for the corresponding $\mathrm{PhNH}_{2} / \mathrm{C}_{2} \mathrm{H}_{4}$ cycle (33.8 $\left.\mathrm{kcal} \mathrm{mol}^{-1}\right){ }^{[11]} \mathrm{Et}_{2} \mathrm{NH}$ coordination to $\mathrm{Pt}^{\mathrm{II}}$ is more favorable than $\mathrm{PhNH}_{2}$ coordination, thus the resting state of the catalytic cycle in this case, according to the computational study, is the diamine complex trans $-\mathrm{PtBr}_{2}\left(\mathrm{NHEt}_{2}\right)_{2}, 7^{\prime}$, rather than complex 1. Complex trans $-\mathrm{PtBr}_{2}\left(\mathrm{PhNH}_{2}\right)_{2}, 7$, on the other hand, was calculated as 3.7 kcal mol ${ }^{-1}$ less stable than $\mathbf{1}^{[11]}$ On the basis of this study, systems I and I' would be predicted as equally competent to catalyze the addition of $\mathrm{Et}_{2} \mathrm{NH}$ and $\mathrm{PhNH}_{2}$ to $\mathrm{C}_{2} \mathrm{H}_{4}$. Hence, the reason for their poorer performance for $\mathrm{NHEt}_{2}$ must be attributed to the catalyst decomposition, which is related to the zwitterion deprotonation by the excess base, as confirmed by our recent study. ${ }^{[16]}$ Note that the protonation transfer step is endoergic on the $\Delta \mathrm{G}^{\mathrm{CPCM}}$ scale for both systems according to the previously published studies, but less so for the NHEt2 system $\left(+15.3 \mathrm{kcal} / \mathrm{mol} \text { for } \mathbf{3}^{\prime}+\mathrm{NHEt}_{2}\right)^{[12]}$ than for the $\mathrm{PhNH}_{2}$ system $\left(+19.8 \mathrm{kcal} / \mathrm{mol}\right.$ for $\left.3+\mathrm{PhNH}_{2}\right){ }^{[11]}$ The catalyst deactivation is then probably driven by the irreversibility of the subsequent steps leading to the metal reduction. 


\section{(c) Catalysis of transalkylation processes.}

Based on these experimental and theoretical premises, we wondered whether catalytic hydroamination with $\mathrm{Et}_{2} \mathrm{NH}$ could be induced through protection of the zwitterionic complex by the addition of acid. Indeed, replacing $\mathrm{H}_{2} \mathrm{O} / \mathrm{NaBr}$ by $\mathrm{HBr}_{\text {aq }}$ gave marginally better results, with TON $=4$ for $\mathrm{Et}_{3} \mathrm{~N}$, see run 3 (Table 2) However, the formation of $\mathrm{EtNH}_{2}$ (ca. 18 cycles) was also observed. In addition to $\mathrm{Et}_{3} \mathrm{~N}, \mathrm{EtNH}_{2}$, and residual $\mathrm{Et}_{2} \mathrm{NH}$, the ${ }^{1} \mathrm{H}$ and ${ }^{13} \mathrm{C}\left\{{ }^{1} \mathrm{H}\right\}$ NMR monitoring also revealed the formation of a minor amount of EtOH (ca. 1 cycle).

Table 2. Additional reactions between $\mathrm{C}_{2} \mathrm{H}_{4}$ and $\mathrm{Et}_{2} \mathrm{NH}^{\left[{ }^{[a]}\right.}$

\begin{tabular}{|l|c|c|c|c|c|}
\hline run & cat. & $\mathrm{C}_{2} \mathrm{H}_{4}$ (bars) & $\mathrm{Et}_{2} \mathrm{NH}(\%$ conv) & $\mathrm{Et}_{3} \mathrm{~N}$ (TON) & $\mathrm{EtNH}_{2}$ (TON) \\
\hline $3^{[\mathrm{b}]}$ & $\mathrm{K}_{2} \mathrm{PtCl}_{4}$ & 25 & 7 & $\sim 4$ & $\sim 18$ \\
\hline $4^{[\mathrm{cc}]}$ & - & 25 & 0 & 0 & 0 \\
\hline 5 & $\mathrm{~K}_{2} \mathrm{PtCl}_{4}$ & 25 & $\sim 0$ & $\sim 1$ & 0 \\
\hline $6^{[\mathrm{d}]}$ & $\mathrm{K}_{2} \mathrm{PtCl}_{4}$ & - & 52 & 92 & 23 \\
\hline 7 & $\mathrm{Pt}^{0}$ & - & 45 & 76 & 18 \\
\hline 8 & $\mathrm{Pt}^{0}$ & 25 & $\sim 0$ & $\sim 1$ & 0 \\
\hline
\end{tabular}

[a] The experimental conditions are identical to those in Table 1, except for the nature and amount of catalyst, olefin and additive as indicated. [b] With 150 eq of $\mathrm{HBr}_{\text {aq. }}(48 \%)$ relative to $\mathrm{Pt}$; a minor amounts of aromatic products $(<1 \%$, resonances in the $\delta 110-150$ range) and $\mathrm{EtOH}$ (ca. $1 \%$, resonances at 17.7 and 57.2) were visible by ${ }^{13} \mathrm{C}\left\{{ }^{1} \mathrm{H}\right\}$ NMR. [c] Same conditions as for run 3 , without catalyst. [d] Minor amounts $(<2 \%)$ of other products were also detected by ${ }^{13} \mathrm{C}\left\{{ }^{1} \mathrm{H}\right\}$ NMR in the aliphatic region.

The next experiments were run with simplified catalytic systems. Run 4 was carried out in the presence of $\mathrm{HBr}$ (same conditions as run 3) without the Pt compound. The result demonstrates the absence of any acid-induced transformation. There are reports warning about the possible action of acids as hydroamination catalysts, ${ }^{[18-19]}$ but they all concern less challenging processes such as intramolecular hydroaminations or the intermolecular addition across activated $\mathrm{C}=\mathrm{C}$ bonds. Furthermore, the conditions employed here are not really acidic, since the amount of acid is a fraction of that of the amine (150 equiv. vs. 350 equiv), hence the reaction mixture contains a $\mathrm{Et}_{2} \mathrm{NH}_{2}+/ \mathrm{Et}_{2} \mathrm{NH}$ buffer. Run 5 was carried out in the absence of acid. These conditions are equivalent to those of run 2 (Table 1), except for the absence of $\mathrm{NaBr}$. The results are also comparable to those of run 2. In fact, an even lower activity was recorded, in agreement with the known activating role of the bromide ions for this catalytic system. ${ }^{[4,6]}$ Further simplification of the system by running the reaction in the absence of ethylene (run 6), unexpectedly gave a large conversion into $\mathrm{Et}_{3} \mathrm{~N}$ and $\mathrm{EtNH}_{2}$. Therefore, no external ethylene is necessary to generate the observed products, proving that these are not resulting from a hydroamination or dehydroamination process. The observed transformation can be rationalized as a simple transalkylation process. Furthermore, comparison of runs 5 and 6 demonstrates that the presence of ethylene inhibits this process.

On the basis of this new evidence, we wondered whether ammonia may also be formed by further transalkylation from the $\mathrm{EtNH}_{2}$ primary product. The ${ }^{14} \mathrm{~N}$ or ${ }^{15} \mathrm{~N}$ analyses of the solution obtained from run 3 did not allow detection of any $\mathrm{NH}_{3}$. However, this result may be a consequence of the small conversion coupled with small sensitivity (for ${ }^{15} \mathrm{~N}$ ) or broad lines (for ${ }^{14} \mathrm{~N}$ ). An additional experiment was carried out starting from $\mathrm{EtNH}_{3}{ }^{+} \mathrm{Cl}^{-}$ rather than from a $\mathrm{Et}_{2} \mathrm{NH} / \mathrm{HBr}$ mixture. $\mathrm{K}_{2} \mathrm{PtCl}_{4}$ was used as the catalyst, without the presence of ethylene, using the standard reaction time and temperature. The final mixture indeed revealed the formation of $\mathrm{NH}_{3}\left(\mathrm{NH}_{4}{ }^{+}\right)$with a resonance at $\delta-357.6$ in the ${ }^{14} \mathrm{~N}$
NMR spectrum, see Figure 2. The spectrum also exhibited a strong resonance at $\delta-344.4$ for the residual $\mathrm{EtNH}_{2} / \mathrm{EtNH}_{3}{ }^{+}$, and a weak one at $\delta-329.1$ for $\mathrm{Et}_{2} \mathrm{NH} / \mathrm{Et}_{2} \mathrm{NH}_{2}{ }^{+}$. The identity of all these resonances was verified by comparison with genuine samples. A resonance for $\mathrm{Et}_{3} \mathrm{~N} / \mathrm{Et}_{3} \mathrm{NH}^{+}$, which should appear around $\delta-325$, is not visible, once again because of the small conversion for this transalkylation process.

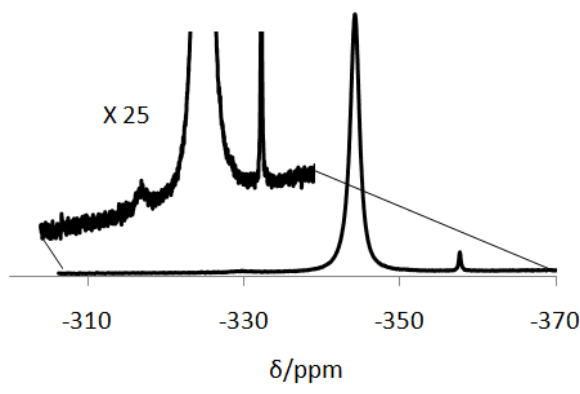

Figure 2. ${ }^{14} \mathrm{~N}$ NMR spectrum of the solution obtained from $\mathrm{EtNH}_{3}{ }^{+} \mathrm{Cl}^{-}$in $\mathrm{D}_{2} \mathrm{O}$, after $10 \mathrm{~h}$ at $150^{\circ} \mathrm{C}$ in the presence of $\mathrm{K}_{2} \mathrm{PtCl}_{4}(0.3 \%)$.

Transalkylation reactions for amine substrates have already been shown to occur under $\mathrm{Pd}^{0}$ catalysis. ${ }^{[20-25]}$ This intrigued us whether the same phenomenon may also occur in the presence of $\mathrm{Pt}^{0}$, because metallic platinum is generated in situ by decomposition of the $\mathrm{Pt}^{\mathrm{II}}$ system as shown above. Platinum-catalyzed amine translakylation has previously been reported only by Brunet $e t$ al., to the best of our knowledge, as a side process during the $\mathrm{PtBr}_{2}-$ catalyzed heterocyclization of aniline to quinolines in the presence of $\mathrm{Bu}_{3} \mathrm{~N}$, but the authors could not establish whether the process is catalyzed by $\mathrm{Pt}^{\mathrm{II}}$ or by the $\mathrm{Pt}^{0}$ formed during the reaction. ${ }^{[26]}$ Indeed, using $\mathrm{Pt}^{0}$ in place of $\mathrm{K}_{2} \mathrm{PtCl}_{4}$ under otherwise identical conditions gave approximately the same conversion and product distribution of the transalkylation products (run 7, Table 2). The ${ }^{13} \mathrm{C}\left\{{ }^{1} \mathrm{H}\right\}$ NMR spectrum of the final reaction mixture is shown in Figure 3. Once again, the process is inhibited by ethylene (run 8).

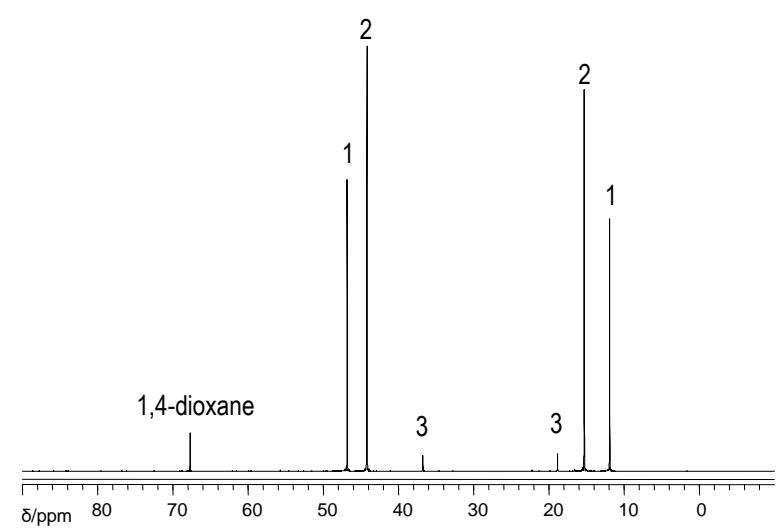

Figure 3. ${ }^{13} \mathrm{C}\left\{{ }^{1} \mathrm{H}\right\}$ NMR spectrum of the final reaction mixture for run 7 (Table 2). 1: $\mathrm{Et}_{3} \mathrm{~N}, 2: \mathrm{Et}_{2} \mathrm{NH}, 3: \mathrm{EtNH}_{2}$ (internal standard: 1,4-dioxane, 1.3 mmol).

The mechanism proposed by Murahashi for the $\mathrm{Pd}^{0}$-catalysed transalkylation process involves metal insertion into the $\alpha-\mathrm{CH}$ bond with formation of a hydrido iminium intermediate. ${ }^{[21]}$ This pathway is illustrated on the left hand side of Scheme 2 for the related $\mathrm{Pt}^{0}$ catalyst. The iminium ligand in this intermediate is then attacked by 
a second amine molecule to generate a coordinated aminoalylammonium ligand, followed by exchange of the proton and the platinum centres and reversal of all steps. Following our recent computational investigation, ${ }^{[10-11,16]}$ however, we can also imagine an alternative pathway involving the reverse steps of the hydroamination reaction, starting with insertion of $\mathrm{Pt}^{0}$ into a $\beta-\mathrm{CH}$ bond and leading to a $\mathrm{Pt}^{0}$-olefin intermediate, followed by hydroamination by a second amine molecule. This pathway is illustrated on the right hand side of Scheme 2. Note, however, that the hydroamination process was shown to occur via $\mathrm{Pt}^{\mathrm{II}} / \mathrm{Pt}^{\mathrm{IV}}$ complexes, whereas in this case the $\mathrm{Pt}^{0} / \mathrm{Pt}^{\mathrm{II}}$ couple would operate.

To test the possibility of the dehydroamination/hydroamination mechanism, we carried out two additional catalytic experiments, using only triethylamine as starting compound, under conditions identical to those of runs 7 and 8 of Table 2. Clearly, the $\alpha-\mathrm{CH}$ bond pathway cannot lead to any reaction, whereas the $\beta-\mathrm{CH}$ bond pathway may result in the generation of $\mathrm{Et}_{2} \mathrm{NH}$, with release of ethylene (dehydroamination). Under the conditions of run 8 , namely in the presence of ethylene pressure, a minor but non negligible amount (ca. 1 cycle) of diethylamine was produced, whereas 5 cycles of the product were observed under the conditions of run 7 (no added ethylene). While these experiments do not exclude that the $\alpha-\mathrm{CH}$ bond activation mechanism is the main pathway when starting from diethylamine, they confirm that the $\beta-\mathrm{CH}$ bond activation mechanism is also taking place under these conditions. The inhibiting effect of the ethylene pressure may be rationalized by a saturation effect of the olefin coordination to the $\mathrm{Pt}^{0}$ surface, blocking or retarding access of the platinum atoms by the $\mathrm{C}-\mathrm{H}$ bonds. This rationalization is compatible, however, with both mechanisms. Additional investigations would be necessary to confirm the presence of an $\alpha-\mathrm{CH}$ bond pathway for this system, which are however outside of the scope of the present work.

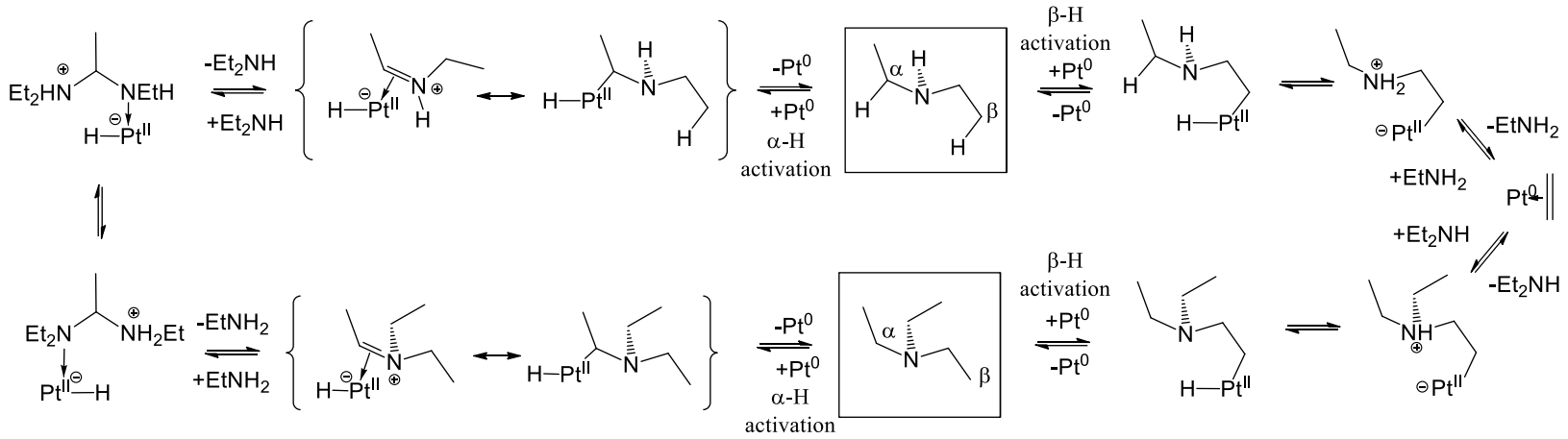

Scheme 2. Two alternative pathways for the $\mathrm{Pt}^{0}$-catalyzed transalkylation reaction.

\section{Conclusions}

The present study has revealed that the catalytic systems I and I', are not efficiently adding the $\mathrm{N}-\mathrm{H}$ bond of $\mathrm{Et}_{2} \mathrm{NH}$ across the $\mathrm{C}=\mathrm{C}$ bond of ethylene, although a computational investigation suggests that they should be as competent to catalyze this transformation as the addition of the aniline N-H bond. The reason is attributed to rapid catalyst degradation with reduction to metallic platinum, favoured by the deprotonation of the key zwitterionic intermediate $\left(3^{6}\right)$, which was shown to form readily by an independent recent study. ${ }^{[12]}$ This deprotonation is favoured by the high basicity of $\mathrm{Et}_{2} \mathrm{NH}$.

Parallel studies have also shown that the produced metallic platinum is responsible for a transmetallation reaction, equilibrating $\mathrm{Et}_{2} \mathrm{NH}$ with $\mathrm{Et}_{3} \mathrm{~N}, \mathrm{EtNH}_{2}$, and even $\mathrm{NH}_{3}$. This appears to be the first report of $\mathrm{Pt}^{0}$-catalyzed amine transalkylation, a process that has previously been well established for $\mathrm{Pd}^{0}$. This process is inhibited by the olefin, presumably because of a surface saturation effect, blocking its access to the substrate $\mathrm{C}-\mathrm{H}$ bonds. Among two different mechanistic pathways involving respectively the activation of the amine $\alpha-\mathrm{CH}$ and $\beta-\mathrm{CH}$ bonds, the latter was shown to be present by a control experiment, although the former could also play a role as previously suggested for the $\mathrm{Pd}^{0}$-catalyzed process. ${ }^{[21]}$

\section{Experimental Section}

General. All solvents were of HPLC grade and were used as received. $\mathrm{HNEt}_{2}$ (Fluka) was distilled and kept under argon in the dark. $\mathrm{PtBr}_{2}$ (Alfa Aesar), $\mathrm{K}_{2} \mathrm{PtCl}_{4}$ (Alfa Aesar) and $\mathrm{nBu}_{4} \mathrm{PBr}$ (Acros Organics) were used as received. Ethylene (purity $\geq 99.5 \%$ ) was purchased from Air Liquide.

Instrumentation. NMR investigations were carried out on Bruker AV400 spectrometer at $298 \mathrm{~K}$ operating at $400.1 \mathrm{MHz}\left({ }^{1} \mathrm{H}\right), 100.6 \mathrm{MHz}\left({ }^{13} \mathrm{C}\right), 28.9$ $\mathrm{MHz}\left({ }^{14} \mathrm{~N}\right)$. The spectra were calibrated with the residual solvent resonance relative to TMS $\left({ }^{1} \mathrm{H},{ }^{13} \mathrm{C}\right)$ and $\mathrm{MeNO}_{2}\left({ }^{14} \mathrm{~N}\right) . \mathrm{D}_{2} \mathrm{O}$ was used for lock.

Typical procedures for the attempted hydroamination of ethylene by $\mathbf{E t}_{2} \mathbf{N H}$. (a) With $\mathbf{P t B r}_{2} /{ }^{\mathrm{B}} \mathrm{Bu}_{4} \mathbf{P B r}$. The autoclave was charged with $\mathrm{PtBr}_{2}$ (46 mg, $0.13 \mathrm{mmol}$ ) and ${ }^{n} \mathrm{Bu}_{4} \mathrm{PBr}$ (440 mg, $1.3 \mathrm{mmol}, 10$ equiv), closed, and submitted to argon/vacuum cycles. $\mathrm{Et}_{2} \mathrm{NH}(4.7 \mathrm{~mL}, 45.5 \mathrm{mmol}, 350$ equiv) was syringed into the autoclave. Finally, the ethylene pressure was adjusted to 25 bar (ca. $100 \mathrm{mmol}, 333$ equiv) at RT. The temperature was then raised to $150^{\circ} \mathrm{C}$. After $10 \mathrm{~h}$, the autoclave was allowed to cool to room temperature and then slowly vented. An external standard (EtOH or 1,4dioxane, $1.3 \mathrm{mmol}$ ) was added to the mixture. The solution was then analyzed by NMR spectroscopy using traces of $\mathrm{CDCl}_{3}$ for instrument lock. (b) with $\mathrm{K}_{2} \mathrm{PtCl}_{4} / \mathrm{HBr}$. The autoclave was charged with $\mathrm{K}_{2} \mathrm{PtCl}_{4}(54 \mathrm{mg}$, $0.13 \mathrm{mmol}$ ), closed, and submitted to argon/vacuum cycles. Water ( or $\mathrm{D}_{2} \mathrm{O}$ ), then $\mathrm{Et}_{2} \mathrm{NH}$ ( $4.7 \mathrm{~mL}, 45.5 \mathrm{mmol}, 350$ equiv), then aqueous $\mathrm{HBr}$ (gently) if necessary, were syringed into the autoclave and the ethylene pressure was adjusted to 25 bar (ca. $100 \mathrm{mmol}, 333$ equiv) at RT. The remainder of the experiment was carried out as above, except that $\mathrm{D}_{2} \mathrm{O}$ was used for the NMR lock. The amount of $\mathrm{D}_{2} \mathrm{O}$ was the minimum needed to homogenize the system.

Typical procedures for the $\mathbf{E t}_{2} \mathbf{N H}$ transalkylation. The autoclave was charged with $\mathrm{K}_{2} \mathrm{PtCl}_{4}$ or Pt black $(0.13 \mathrm{mmol})$, closed, and submitted to argon/vacuum cycles. $\mathrm{Et}_{2} \mathrm{NH}$ or $\mathrm{Et}_{3} \mathrm{~N}$ ( $45.5 \mathrm{mmol}, 350$ equiv) was then added and the ethylene pressure (if needed) was adjusted to 25 bar (ca. 100 
mmol, 333 equiv) at RT. The remainder of the experiment was carried out as above. A minor amount of $\mathrm{D}_{2} \mathrm{O}$ was added for the NMR lock.

Computational Details. The DFT calculations were carried out using the same methodology described in detail in our recent studies of the $\mathrm{C}_{2} \mathrm{H}_{4} / \mathrm{PhNH}_{2}$ reaction, ${ }^{[10-11]}$ namely using the B3LYP functional and the standard $6-31+\mathrm{G}^{*}$ basis set for all atoms except $\mathrm{Pt}$, for which the LANL2TZ(f) basis was used. ${ }^{[27]}$ The calculations included a frequency analysis for all minima and transition states and solvation effects by singlepoint C-PCM ${ }^{[28-29]}$ corrections on the gas-phase optimized geometries, from which the thermodynamic $\Delta \mathrm{G}^{\mathrm{CPCM}}$ values were derived. All new optimized geometries are available in the SI.

Supporting Information (see footnote on the first page of this article): List of optimized Cartesian coordinates for all new geometries ( 2 pages).

\section{Acknowledgments}

We are grateful to the CNRS (Centre National de la Recherche Scientifique), the ANR (Agence Nationale de la Recherche, Grant No. NT09_442499), the IUF (Institut Universitaire de France) for financial support, as well as the CINES (Centre Informatique National de l'Enseignement Supérieur) and the CICT (Centre Interuniversitaire de Calcul de Toulouse, project CALMIP) for granting free computational time. PD thanks the MENESR (Ministère de l'Éducation Nationale, de l'Enseignement Supérieur et de la Recherche, France) for a Ph.D. fellowship.

[1] J.-J. Brunet, D. Neibecker, in Catalytic Heterofunctionalization (Eds.: A. Togni, H. Grützmacher), VCH, Weinheim, 2001, pp. 91141.

[2] J.-J. Brunet, N.-C. Chu, M. Rodriguez-Zubiri, Eur. J. Inorg. Chem. 2007, 4711-4722.

[3] T. E. Müller, K. C. Hultzsch, M. Yus, F. Foubelo, M. Tada, Chem. Rev. 2008, 108, 3795-3892.

[4] J. J. Brunet, M. Cadena, N. C. Chu, O. Diallo, K. Jacob, E. Mothes, Organometallics 2004, 23, 1264-1268.

[5] J. J. Brunet, N. C. Chu, O. Diallo, Organometallics 2005, 24, 31043110.

[6] P. A. Dub, M. Rodriguez-Zubiri, C. Baudequin, R. Poli, Green Chem. 2010, 1392-1396.

[7] X. Wang, R. A. Widenhoefer, Organometallics 2004, 23, 1649-1651.
[8] D. Karshtedt, A. T. Bell, T. D. Tilley, J. Am. Chem. Soc. 2005, 127, 12640-12646.

[9] P. A. Dub, M. Rodriguez-Zubiri, J.-C. Daran, J.-J. Brunet, R. Poli, Organometallics 2009, 28, 4764-4777.

[10] P. A. Dub, R. Poli, J. Mol. Catal. A 2010, 324, 89-96.

[11] P. A. Dub, R. Poli, J. Am. Chem. Soc. 2010, 132, 13799-13812.

[12] P. A. Dub, J.-C. Daran, V. A. Levina, N. V. Belkova, E. S. Shubina, R. Poli, J. Organomet. Chem 2011, 696, 1174-1183.

[13] J. K. K. Sarhan, M. Green, I. M. Al-Najjar, J. Chem. Soc., Dalton Trans. 1984, 771-777.

[14] G. Lorusso, C. R. Barone, N. G. Di Masi, C. Pacifico, L. Maresca, G. Natile, Eur. J. Inorg. Chem. 2007, 2144-2150.

[15] G. Balacco, G. Natile, J. Chem. Soc., Dalton Trans. 1990, 3021-3024.

[16] P. A. Dub, A. Béthegnies, R. Poli, Organometallics submitted.

[17] R. Poli, Comm. Inorg. Chem. 2009, 30, 177-228.

[18] B. Schlummer, J. F. Hartwig, Org. Lett. 2002, 4, 1471-1474.

[19] J. G. Taylor, L. A. Adrio, K. K. Hii, Dalton Trans. 2010, 39, 11711175 .

[20] N. Yoshimura, I. Moritani, T. Shimamura, S. I. Murahashi, J. Am. Chem. Soc. 1973, 95, 3038-3039.

[21] S. I. Murahashi, T. Hirano, T. Yano, J. Am. Chem. Soc. 1978, 100, 348-350.

[22] S. I. Murahashi, T. Yano, Chem. Commun. 1979, 270-271.

[23] Y. Shvo, R. M. Laine, Chem. Commun. 1980, 753-754.

[24] S. I. Murahashi, N. Yoshimura, T. Tsumiyama, T. Kojima, J. Am. Chem. Soc. 1983, 105, 5002-5011.

[25] S. I. Murahashi, Angew. Chem. Engl. 1995, 34, 2443-2465.

[26] S. Anguille, J.-J. Brunet, N. C. Chu, O. Diallo, C. Pages, S. Vincendeau, Organometallics 2006, 25, 2943-2948.

[27] L. E. Roy, P. J. Hay, R. L. Martin, J. Chem. Theory Comput. 2008, 4, 1029-1031.

[28] V. Barone, M. Cossi, J. Phys. Chem. A 1998, 102, 1995-2001.

[29] M. Cossi, N. Rega, G. Scalmani, V. Barone, J. Comput. Chem. 2003, 24, 669-681.

Received: ((will be filled in by the editorial staff)) Published online: ((will be filled in by the editorial staff)) 


\section{Entry for the Table of Contents}

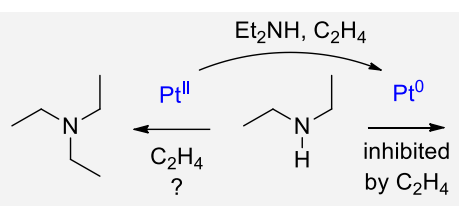

$\mathrm{Pt}^{\mathrm{II}}$ salts and $\mathrm{Pt}^{0}$ promote different reactions for the amine/ethylene combination. $\mathrm{Pt}^{\mathrm{II}}$ is a catalyst for the

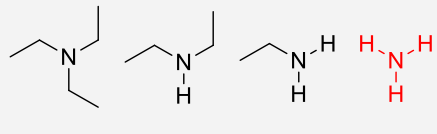

hydroamination process, whereas $\mathrm{Pt}^{0}$ promotes transalkylation, a reaction which is inhibited by the olefin.

Hydroamination vs. transalkylation

Pavel A. Dub and Rinaldo Poli* Page No. - Page No.

Reactions of diethylamine and ethylene catalyzed by $\mathrm{Pt}^{\mathrm{II}}$ or $\mathrm{Pt}^{0}$ : transalkylation vs. hydroamination

Keywords: Platinum / ethylene hydroamination / amine transalkylation / DFT calculations / aqueous catalysis 


\title{
Reactions of diethylamine and ethylene catalyzed by $\mathrm{Pt}^{\mathrm{II}}$ or $\mathrm{Pt}^{\mathrm{0}}$ : transalkylation $v s$. hydroamination.
}

\author{
Pavel A. Dub, ${ }^{\mathrm{a}}$ and Rinaldo Poli*,a,b
}

${ }^{a}$ CNRS; LCC (Laboratoire de Chimie de Coordination); Université de Toulouse; UPS, INP; F-31077

Toulouse, France; 205, route de Narbonne, F-31077 Toulouse, France; Fax: (+) 33-561553003; Email:poli@lcc-toulouse.fr

${ }^{b}$ Institut Universitaire de France, 103, bd Saint-Michel, 75005 Paris, France

\section{SUPPORTING INFORMATION}

Table S1. Cartesian coordinates for all new optimized structures.

\begin{tabular}{|c|c|c|c|}
\hline \multicolumn{4}{|c|}{$\left[\right.$ trans-PtF $\left.{ }_{2}\left(\mathrm{HNEt}_{2}\right)\right] 6$} \\
\hline \multicolumn{4}{|c|}{ SCF DONE: -5689.757768 } \\
\hline $\mathrm{H}$ & -4.542268000 & -0.729073000 & -2.269058000 \\
\hline $\mathrm{H}$ & -3.716283000 & -2.181533000 & -1.687123000 \\
\hline $\mathrm{H}$ & -4.684750000 & -1.193886000 & -0.571183000 \\
\hline $\mathrm{C}$ & -3.994261000 & -1.153677000 & -1.420202000 \\
\hline $\mathrm{H}$ & -3.039300000 & 0.714621000 & -0.818520000 \\
\hline $\mathrm{C}$ & -2.762673000 & -0.290150000 & -1.139577000 \\
\hline $\mathrm{H}$ & -2.163997000 & -0.176913000 & -2.047276000 \\
\hline $\mathrm{N}$ & -1.838172000 & -0.862951000 & -0.109228000 \\
\hline $\mathrm{H}$ & -1.576739000 & -1.798488000 & -0.437661000 \\
\hline $\mathrm{H}$ & -2.227166000 & 0.922679000 & 2.021065000 \\
\hline
\end{tabular}

$\begin{array}{ccc}-3.841836000 & 0.600657000 & 1.369572000 \\ -3.365738000 & -0.110802000 & 2.915873000 \\ -3.002209000 & 0.159243000 & 1.917418000 \\ -2.464044000 & -1.094874000 & 1.239493000 \\ -1.682458000 & -1.557138000 & 1.847515000 \\ -3.265116000 & -1.835589000 & 1.119337000 \\ 0.066123000 & 0.027448000 & -0.029007000 \\ -0.761224000 & 2.381085000 & -0.102415000 \\ 0.892481000 & -2.328617000 & 0.037704000 \\ 1.975072000 & 0.915211000 & 0.024775000 \\ 1.729554000 & 1.845155000 & 0.380508000 \\ 2.554710000 & 1.175992000 & -1.338821000 \\ 3.918729000 & 0.895746000 & 0.837516000 \\ 2.977765000 & 0.344084000 & 0.977302000\end{array}$




$\begin{array}{lrrr}\mathrm{C} & 2.513747000 & 0.449389000 & 2.426003000 \\ \mathrm{H} & 3.294263000 & 0.058542000 & 3.088709000 \\ \mathrm{H} & 3.146009000 & -0.697867000 & 0.702766000 \\ \mathrm{H} & 2.318076000 & 1.490354000 & 2.713172000 \\ \mathrm{H} & 1.601550000 & -0.131995000 & 2.588342000 \\ \mathrm{C} & 2.990007000 & -0.071219000 & -2.098985000 \\ \mathrm{H} & 3.355632000 & 0.230925000 & -3.087541000 \\ \mathrm{H} & 3.802312000 & -0.604244000 & -1.593790000 \\ \mathrm{H} & 2.158509000 & -0.767937000 & -2.231290000 \\ \mathrm{H} & 1.783057000 & 1.716163000 & -1.893261000 \\ \mathrm{H} & 3.409850000 & 1.854795000 & -1.204839000\end{array}$

$\left[\mathrm{PtBr}_{3}\left(\mathrm{C}_{2} \mathrm{H}_{4} \mathrm{NHEt}_{2}\right)\right]^{-} 4$

\section{SCF DONE: -8126.038077}

$\begin{array}{lrrr}\mathrm{H} & -2.104365000 & 3.182480000 & 2.643258000 \\ \mathrm{H} & -0.985991000 & 1.798682000 & 2.580794000 \\ \mathrm{C} & -1.696418000 & 2.394545000 & 1.998264000 \\ \mathrm{H} & -3.329584000 & 1.008874000 & 2.319265000 \\ \mathrm{C} & -2.844775000 & 1.527831000 & 1.485591000 \\ \mathrm{H} & -3.608691000 & 2.126870000 & 0.977219000 \\ \mathrm{~N} & -2.378493000 & 0.478445000 & 0.517194000 \\ \mathrm{H} & -3.256952000 & 0.941364000 & -1.364721000 \\ \mathrm{H} & -1.926917000 & 2.010390000 & -0.848656000 \\ \mathrm{H} & -1.337036000 & 0.244029000 & 0.690546000 \\ \mathrm{C} & -1.181638000 & 0.151700000 & -1.649473000 \\ \mathrm{H} & -0.879370000 & 0.722426000 & -2.537086000 \\ \mathrm{H} & -1.582681000 & -0.812310000 & -1.988609000 \\ \mathrm{H} & -2.578626000 & -1.541854000 & 0.016566000 \\ \mathrm{C} & -3.109046000 & -0.828566000 & 0.652034000 \\ \mathrm{H} & -2.949035000 & -1.154960000 & 1.684873000 \\ \mathrm{C} & -4.598830000 & -0.760950000 & 0.328873000 \\ \mathrm{H} & -5.136338000 & -0.042029000 & 0.959191000 \\ \mathrm{H} & -5.036263000 & -1.750058000 & 0.508132000 \\ \mathrm{H} & -4.784598000 & -0.507012000 & -0.719644000 \\ \mathrm{Br} & -0.083000000 & -2.573941000 & -0.273127000 \\ \mathrm{Pt} & 0.458235000 & -0.128152000 & -0.397091000 \\ \mathrm{Br} & 0.962242000 & 2.315335000 & -0.719374000 \\ \mathrm{H} & -1.127794000 & 2.855983000 & 1.185313000 \\ \mathrm{C} & -2.252005000 & 0.970351000 & -0.923565000 \\ \mathrm{Br} & 2.424404000 & -0.403268000 & 1.275244000\end{array}$

\section{$\left[\operatorname{PtBr}_{3}\left(\mathrm{C}_{2} \mathrm{H}_{4} \mathrm{NHEt}_{2}\right)\right]^{-} \mathrm{TS}$}

\section{SCF DONE: -8126.017479}

$\begin{array}{lccc}\mathrm{H} & 4.431289000 & -2.828971000 & 1.824518000 \\ \mathrm{H} & 3.042498000 & -1.847482000 & 2.365568000 \\ \mathrm{C} & 3.632913000 & -2.150041000 & 1.494035000 \\ \mathrm{H} & 4.867582000 & -0.387816000 & 1.532235000 \\ \mathrm{C} & 4.236714000 & -0.919237000 & 0.807997000 \\ \mathrm{H} & 4.911166000 & -1.242616000 & -0.010943000 \\ \mathrm{~N} & 3.220563000 & 0.021285000 & 0.331336000 \\ \mathrm{H} & 3.265835000 & -0.234385000 & -1.794269000 \\ \mathrm{H} & 2.401956000 & -1.468194000 & -0.865599000 \\ \mathrm{H} & 0.918916000 & 0.174516000 & 0.254494000 \\ \mathrm{C} & 1.269178000 & 0.306892000 & -1.223532000 \\ \mathrm{H} & 0.849623000 & -0.122226000 & -2.137791000 \\ \mathrm{H} & 1.374329000 & 1.385166000 & -1.347657000 \\ \mathrm{H} & 2.736519000 & 2.046939000 & 0.218158000 \\ \mathrm{C} & 3.623238000 & 1.429400000 & 0.395370000 \\ \mathrm{H} & 3.924821000 & 1.629959000 & 1.431878000 \\ \mathrm{C} & 4.755759000 & 1.871992000 & -0.553414000 \\ \mathrm{H} & 5.679058000 & 1.305058000 & -0.377355000 \\ \mathrm{H} & 4.979443000 & 2.935297000 & -0.395518000\end{array}$

$\begin{array}{lccc}\mathrm{H} & 4.479459000 & 1.746570000 & -1.607079000 \\ \mathrm{Br} & -0.768344000 & 2.527908000 & 0.139985000 \\ \mathrm{Pt} & -0.620385000 & 0.041713000 & -0.113132000 \\ \mathrm{Br} & -0.354392000 & -2.440329000 & -0.371164000 \\ \mathrm{H} & 2.966313000 & -2.707741000 & 0.828742000 \\ \mathrm{C} & 2.594798000 & -0.394482000 & -0.924018000 \\ \mathrm{Br} & -3.038931000 & -0.220545000 & 0.419948000\end{array}$

trans $-\left[\mathrm{PtF}_{2}\left(\mathrm{C}_{2} \mathrm{H}_{4}\right)\left(\mathrm{PhNH}_{2}\right)\right] \mathbf{5}$

SCF DONE: -685.150356

$\begin{array}{llll}78 & -1.003000000 & 0.000556000 & -0.094129000\end{array}$

$\begin{array}{llll}9 & -0.957709000 & 1.975517000 & -0.142570000\end{array}$

$\begin{array}{llll}7 & 0.722778000 & 0.013187000 & -1.330241000\end{array}$

$\begin{array}{lll}-0.944481000 & -1.973790000 & -0.152465000\end{array}$

$\begin{array}{lll}-3.059819000 & -0.007446000 & 0.474548000\end{array}$

$\begin{array}{lll}-2.267246000 & -0.011668000 & 1.628413000\end{array}$

$\begin{array}{lll}-2.082288000 & 0.911774000 & 2.172500000\end{array}$

$\begin{array}{lll}-2.076889000 & -0.940319000 & 2.161645000\end{array}$

$\begin{array}{lll}-3.494540000 & -0.932360000 & 0.102205000\end{array}$

$\begin{array}{lll}-3.498969000 & 0.919392000 & 0.112257000\end{array}$

$\begin{array}{lll}1.981448000 & 0.006284000 & -0.600006000\end{array}$

$\begin{array}{lll}0.649515000 & -0.810354000 & -1.930303000\end{array}$

$\begin{array}{lll}0.647749000 & 0.849823000 & -1.911776000\end{array}$

$\begin{array}{llll}2.564827000 & -1.213044000 & -0.248144000\end{array}$

$\begin{array}{lll}3.766929000 & -1.213218000 & 0.463163000\end{array}$

$\begin{array}{lll}4.375866000 & -0.007365000 & 0.824261000\end{array}$

$\begin{array}{lll}3.772263000 & 1.205310000 & 0.477540000\end{array}$

$2.570265000 \quad 1.218740000 \quad-0.233928000$

$2.071748000 \quad-2.146346000 \quad-0.507333000$

$\begin{array}{lll}4.223840000 & -2.159999000 & 0.737754000\end{array}$

$\begin{array}{lll}5.311320000 & -0.012698000 & 1.376722000\end{array}$

$\begin{array}{lll}4.233327000 & 2.146788000 & 0.763201000\end{array}$

$\begin{array}{lll}2.082241000 & 2.157507000 & -0.482909000\end{array}$

\section{$\left[\mathrm{PtBr}_{3}\left(\mathrm{CH}_{3} \mathrm{CH}_{2} \mathrm{NEt}_{2}\right)\right]^{-5}$}

SCF DONE: -8126.031875

$\begin{array}{lccc}\mathrm{H} & 4.284230000 & -2.872651000 & 1.770679000 \\ \mathrm{H} & 3.307991000 & -1.545087000 & 2.452857000 \\ \mathrm{C} & 3.683570000 & -1.986447000 & 1.522727000 \\ \mathrm{H} & 5.360966000 & -0.641196000 & 1.407734000 \\ \mathrm{C} & 4.536353000 & -0.967271000 & 0.759497000 \\ \mathrm{H} & 5.007241000 & -1.457718000 & -0.116705000 \\ \mathrm{~N} & 3.780004000 & 0.226367000 & 0.375375000 \\ \mathrm{H} & 3.445995000 & 0.215841000 & -1.737897000 \\ \mathrm{H} & 2.596878000 & -1.019592000 & -0.813617000 \\ \mathrm{H} & 1.062668000 & 0.578673000 & 0.166355000 \\ \mathrm{C} & 1.644825000 & 0.884163000 & -0.753612000 \\ \mathrm{H} & 1.076810000 & 0.763014000 & -1.680932000 \\ \mathrm{H} & 1.813687000 & 1.955089000 & -0.607798000 \\ \mathrm{H} & 3.894989000 & 2.290237000 & 0.142706000 \\ \mathrm{C} & 4.576059000 & 1.452814000 & 0.334936000 \\ \mathrm{H} & 4.982267000 & 1.617399000 & 1.342829000 \\ \mathrm{C} & 5.735800000 & 1.505185000 & -0.682885000 \\ \mathrm{H} & 6.478463000 & 0.720909000 & -0.490298000 \\ \mathrm{H} & 6.247944000 & 2.474498000 & -0.616247000 \\ \mathrm{H} & 5.383063000 & 1.387391000 & -1.714151000 \\ \mathrm{Br} & -1.345096000 & 2.478063000 & 0.183747000 \\ \mathrm{Pt} & -0.827127000 & 0.065005000 & -0.083691000 \\ \mathrm{Br} & -0.061464000 & -2.278182000 & -0.445760000 \\ \mathrm{H} & 2.814669000 & -2.316700000 & 0.943876000 \\ \mathrm{C} & 2.909262000 & 0.027625000 & -0.787382000 \\ \mathrm{Br} & -3.113933000 & -0.608494000 & 0.293189000\end{array}$

